\title{
OPIEKA NAD CHORYMI JAKO DROGA DO ŚWIĘTOŚCI WEDŁUG ŚW. DOROTEUSZA Z GAZY
}

Chrześcijanie od początku wielką troską otaczali chorych. Chrystus, Słowo Wcielone Ojca, swoim życiem, śmiercią i zmartwychwstaniem, swoimi czynami i słowami objawił prawdę o niczym nieograniczonej miłości Boga Ojca, a zarazem o wielkiej godności człowieka, który stworzony na obraz i podobieństwo Boga jest wezwany pomimo słabości i grzechów, aby dzielić szczęście i wieczność Stwórcy. Chrześcijanie na mocy nowej i oryginalnej wizji człowieka, która objawiła się w życiu i słowach Chrystusa od razu wyciągają wnioski do szeroko rozumianej kultury sanitarnej. Zbawiciel dając przykazanie miłości bliźniego sam żyje tą normą i często potwierdza, że przyszedł, aby zbawić człowieka z duszą i ciałem. Do paralityka mówi: „Oto wyzdrowiałeś. Nie grzesz już więcej, aby ci się coś gorszego nie przydarzyło” (J 5, 14). Pośród prerogatyw Mesjasza jest również moc uzdrawiania chorych (por. Łk 7,21). Ludzie odkryli tę łaskę i ,liczne tłumy zbierały się, aby Go słuchać i znaleźć uzdrowienie ze swych niedomagań” (Łk 5,15). Relacje ewangelistów pokazują, że apostołowie byli pod wrażeniem niezwykłych uzdrowień i troski Chrystusa o chorych i cierpiących. Miłość Chrystusa do chorych najlepiej pokazuje przypowieść o miłosiernym Samarytaninie (por. Łk 10, 30-37), w której podkreślone są dwa aspekty kultury sanitarnej jaką proponuje Jezus: miłość bliźniego rozszerzona poza granice współziomków oraz przynajmniej minimalna znajomość sztuki medycznej (wino, olej i bandaże) ${ }^{1}$. Warto dodać, że dla wielu Ojców Kościoła zdrowie było w pewnym sensie wartością „obojętną" z punktu widzenia życia duchowego, a stawało się dobre lub złe stosownie do dyspozycji tego, którego dotykała choroba, i do sposobu przeżywania cierpienia i braku zdrowia ${ }^{2}$.

1. Uczniowie Chrystusa wobec chorych. Uczniowie Chrystusa na mocy nakazu Mistrza mają leczyć chorych i wyrzucać demony (por. Łk 10, 9). Od

\footnotetext{
${ }^{*}$ Bp dr hab. Piotr Turzyński - adiunkt w Katedrze Patrologii Greckiej i Łacińskiej w Instytucie Historii Kościoła i Patrologii na Wydziale Teologii Katolickiego Uniwersytetu Lubelskiego Jana Pawła II; e-mail: pturzynski@episkopat.pl.

${ }^{1}$ Por. A. Cesera, L'Ospedale e l'assistenza ai malati nel corso dei secoli, Brezzo di Bedero 1994, 36.

${ }^{2}$ Por. J.-C. Larchet, Le chrétien devant la maladie, la souffrance et la mort, Paris 2002, 63.
} 
początku więc opieka nad chorymi i sztuka medyczna w chrześcijaństwie stają się wyrazem miłości do Chrystusa a nie źródłem dochodu ${ }^{3}$. Motywem głównym stają się słowa Chrystusa: „Wszystko, co uczyniliście jednemu z tych braci moich najmniejszych, Mnieście uczynili” (Mt 25, 40). Bardzo jasno mówi o tym święty Benedykt w swojej Regule:

„O chorych należy troszczyć się przede wszystkim i ponad wszystko i służyć im rzeczywiście tak, jak Chrystusowi. [...] Ale i sami chorzy niech pamiętaja, że bracia służą im dla chwały Bożej i niech przez nadmierne wymagania nie sprawiają przykrości tym, którzy się nimi opiekują"4.

Istotnymi znakami troski o chorych w Kościele było ustanowienie diakonów (por. Dz 6, 3-4), a potem w czasie pontyfikatu papieża Fabiana (240-253) podział Rzymu na 7 rejonów w celu opieki nad potrzebującymi oraz ustanowienie przy siedzibach biskupich pomieszczeń o charakterze medycznym $i$ charytatywnym nazywanych diakoniami ${ }^{5}$. Po uzyskaniu edyktu tolerancyjnego dokumenty Kościoła nakazywały budowanie czy przeznaczenie w miastach pomieszczeń (ksenodochia) dla pielgrzymów, obcokrajowców czy chorych ${ }^{6}$.

W bogatej i nie dającej się ująć w sztywne ramy duchowości Ojców Pustyni znajdziemy również wskazania jak wielką wartość ma opieka nad starszymi i chorymi. Jeden $z$ apoftegmatów mówi:

„Spytał brat pewnego starca: «Są dwaj bracia, z których jeden skupia się w swojej celi i przedłuża swe posty do sześciu dni i podejmuje liczne umartwienia, drugi natomiast usługuje chorym. Którego z nich dzieło milsze jest Bogu?» Starzec odrzekł: «Chociażby ów brat, który podejmuje sześciodniowe posty, powiesił się za nozdrza, nie będzie nigdy równać się z tym, który usługuje chorym»"

Ojcowie i matki pustyni zachowywali właściwą równowagę w rozumieniu Ewangelii i poszukiwaniu własnej doskonałości. Nie byli oni egoistami uciekającymi od świata pełnego cierpienia ${ }^{8}$ i ludźmi wyizolowanymi od innych. Znamienny jest apoftegmat opowiadający jak abba Agaton, gdy sprzedawał w mieście kosze zrobione przez siebie na pustyni, spotkał chorego człowie-

\footnotetext{
${ }^{3}$ Por. Cesera, L'Ospedale e l'assistenza ai malati, s. 37.

${ }^{4}$ Benedictus, Regula 36, ed. i thum. A. Świderkówna: Święty Benedykt z Nursji, Reguła, Kraków 1994, 152-155.

${ }^{5}$ Por. Cesera, L'Ospedale e l'assistenza ai malati, s. 42.

${ }^{6}$ Por. S. Longosz, Ksenodochium - hospicjum wczesnochrześcijańskie, VoxP 16 (1996) t. 30-31, 273-336; B. Pawłowska-Blachaczek, ,, Corpora sanctorum in pace sepulta sunt, et nomina eorum vivent in aeternum". Peregrinatio christiana do Rzymu w czasach Grzegorza Wielkiego, VoxP 30 (2010) t. 55, 77-93.

${ }^{7}$ Apophtegmata Patrum, Collectio systematica (Verba seniorum) XVII 18, PL 73, 976B, thum. M. Kozera: Apoftegmaty Ojców Pustyni, t. 2: Kolekcja systematyczna, ŹM 9, Kraków 1995, 288-289.

${ }^{8}$ Por. J. Chryssavgis, W sercu pustyni. Duchowość Ojców i Matek pustyni, tłum. M. Chojnacki, Kraków 2007, 74-77.
} 
ka i opiekował się nim cztery miesiące dopóki ten nie odzyskał zdrowia, po czym wrócił do swojej celi ${ }^{9}$. Miłość bliźniego, także w radykalnych formach naśladowania Chrystusa, przejawiała się poprzez dobry przykład, modlitwe, zastępczą pokutę, ale także przez jałmużnę, działalność wychowawczą oraz służbę chorym i pielgrzymom ${ }^{10}$. Andrew Todd Crislip w swojej monografii pokazuje, że w monastycyzmie przedbazyliańskim, a zwłaszcza w cenobium Pachomiusza znany był szeroki zakres opieki socjalnej i medycznej obejmujący biednych, obcych, sieroty, starszych i trędowatych. Podobieństwa są tak wielkie, że w monastycznym systemie opieki nad chorymi należy widzieć początki szpitalnictwa. Zmianą i krokiem milowym było zorganizowanie przez Bazylego Wielkiego w Bazyliadzie w latach 369-372 szpitala otwartego nie tylko dla mnichów, ale dla wszystkich. Jest on najprawdopodobniej pierwszym szpitalem, w którym realizują się trzy podstawowe cechy decydujące o tej nazwie. Są nimi: stacjonarny pobyt, profesjonalny personel medyczny i charytatywna opieka ${ }^{11}$.

2. Doroteusz i jego doświadczenie. W VI w. mnich palestyński Doroteusz z Gazy w swoich konferencjach duchowych bardzo dużo miejsca poświęcił tematowi opieki nad chorymi i wartości tej troski w oczach Boga. Doroteusz urodził się ok. 500 r. w Antiochii w zamożnej rodzinie chrześcijańskiej, odbył studia klasyczne, studiował także księgi medyczne, po czym wstąpił ok. 20 roku życia do kierowanego przez opata Seridosa klasztoru w Thawatha ${ }^{12}$. Osada Thawatha była podobna w swej strukturze do pustelniczych osad egipskich. W centrum stał kościół. Obok piekarni, kuchni, sadu i ogrodu oraz tłoczni, biblioteki i skryptorium istniała też infirmeria dla chorych. Monastycyzm palestyński, podobnie jak syryjski, rozwijał się samodzielnie, choć ze względu na bliskość położenia wpływy egipskie były tu silniejsze niż w Syrii. Za ojca eremityzmu palestyńskiego uważany jest urodzony w Thawatha św. Hilarion, który przez pewien czas był uczniem św. Antoniego. Duchowość jak i zewnętrzny styl organizacyjny monastycyzmu palestyńskiego ukształtowany był na wzór egipskiego życia pustelniczego ${ }^{13}$.

W początkach swego życia monastycznego Doroteusz przeszedł okres wielkich trudności wewnętrznych, wynikających z wielu przyczyn. Ponieważ był dość słabego zdrowia, nie pozwolono mu na nadmierne posty i umartwie-

\footnotetext{
${ }^{9}$ Por. Apophtegmata Patrum, Collectio alphabetica 109 (Agathon 27), PG 65, 115, thum. M. Borkowska: Apoftegmaty Ojców Pustyni, t. 1. Gerontikon. Księga starców, ŹM 4, Kraków 2004, 170.

${ }^{10}$ Por. T. Špidlik, Duchowość chrześcijańskiego Wschodu. Poradnik systematyczny, thum. L. Rodziewicz, Kraków 2005, 224.

${ }^{11}$ Por. A.T. Crislip, From Monastery to Hospital. Christian Monasticism and the Transformation of Health Care in Late Antiquity, Michigan 2005, 138; G.B. Ferngren, Medicine and Health Care in Early Christianity, Baltimore 2009, 124.

${ }_{12}$ Por. M. Borkowska, Wstęp, w: Starcy spod Gazy. Wybór pism Barsanufiusza, Jana, św. Doroteusza z Gazy, BOK 11, Kraków 1999, 9.

${ }^{13}$ Por. L. Nieścior, Wstęp, w: Doroteusz z Gazy, Pisma ascetyczne, ŹM 51, Kraków 2010, 16-17.
} 
nia pokutne, które były praktykowane w klasztorze Seriodosa. Po drugie, powierzono mu liczne funkcje, które z jednej strony nie pozwalały zamykać się w sobie, ale $\mathrm{z}$ drugiej były źródłem wielu pokus i problemów. I po trzecie, jak każdy początkujący miał okresy niepewności, zwątpienia i zniechęcenia. Jego ojcowie duchowni Barsanufiusz i Jan z wielką cierpliwością prostowali jego błędy i podtrzymywali go na duchu. Uczyli go pokornie odkrywać swoje słabości i ufać w łaskę Bożą ${ }^{14}$. Bardzo wcześnie, bo po kilku latach wstępnej formacji, Starcy powierzają Doroteuszowi odpowiedzialne funkcje, które pozwalają mu spotykać się z ludźmi potrzebującymi pomocy i uczą dźwigać ich ciężary. Przez jakiś czas był on furtianem i zwierzchnikiem domu gościnnego, a następnie nakazano mu założyć i prowadzić infirmerię, której dotychczas nie było. W ten sposób zostało wykorzystane doświadczenie Doroteusza zdobyte w świecie i jego znajomość medycyny. Brat Doroteusza jako gorliwy chrześcijanin i sympatyk mnichów pokrył koszty budowy pomieszczeń dla chorych ${ }^{15}$. Pomocnikiem i zarazem pierwszym uczniem Doroteusza został Dozyteusz. Po kilku latach Dozyteusz śmiertelnie zachorował i umarł w opinii świętości.

Nieco później Doroteusz otrzymał zaszczytną funkcję usługiwania Janowi, jednemu z dwóch rekluzów. Wśród trudności i pokus związanych z obowiązkami, które go rozpraszały i z kierowniczym stanowiskiem przeżył kolejną fazę zniechęcenia i marzeń o pustelni, jednak Jan wyperswadował mu te marzenia, tłumacząc, że życie pustelnicze, jakkolwiek samo w sobie jest dobre, może stać się dla niedoskonałych okazją do pychy i zguby, on zaś powinien pokornie iść drogą „pośrednią”, drogą pokory, posłuszeństwa i współczucia dla bliźnich ${ }^{16}$. To będą trzy istotne elementy jego duchowości.

Barsanufiusz i Jan znaleźli w osobie Doroteusza wyjątkowo zdolnego i podatnego na nauki ucznia. W czasie pobytu w klasztorze prowadzili go drogą wolności wewnętrznej, osiaganej przez całkowite poddanie się ojcom duchowym i przez nieprzerwaną walkę z własnymi namiętnościami. Doroteusz szedł po tej drodze milowymi krokami i wkrótce sam zasłynął jako człowiek mający Boży dar duchowego ojcostwa ${ }^{17}$. Powszechna opinia utrzymuje, że Doroteusz odszedł z Thawatha na pustynię i nieopodal założył własny klasztor, który stał się kolejnym ośrodkiem kultury monastycznej ${ }^{18}$. Wokół niego zaczęli gromadzić się uczniowie, widząc w nim nowego mistrza duchowego. Predestynowała go do tego gorliwość w wyznawaniu tradycji Ojców, jak również niepospolity intelekt $\mathrm{i}$ wszechstronne wykształcenie. Uczniowie cenili sobie jego konferencje ze względu na jasny wykład, doskonałą zgodność z naukami

\footnotetext{
${ }^{14}$ Por. M. Borkowska, [Wstęp] do Listy do Doroteusza, w: BOK 11, 38.

${ }^{15}$ Por. Dorotheus Gazaeus, Vita s. Dosithei 1, PG 88, 122, thum. M. Borkowska: Doroteusz z Gazy, Żywot św. Dozyteusza, ŹM 51, 58. Zob. J.L. Hevelone-Harper, Uczniowie pustyni. Mnisi świeccy i prymat ducha w Gazie VI wieku, tłum. E. Dąbrowska, ŹM 52, Kraków 2010, 149.

${ }^{16}$ Por. M. Borkowska, Twarze Ojców Pustyni, Kraków 2001, 151.

${ }^{17}$ Por. taż, Wstęp, w: Św. Doroteusz z Gazy, Nauki ascetyczne, PSP 27, Warszawa 1980, 7.

${ }^{18}$ Por. Hevelone-Harper, Uczniowie pustyni, s. 166-173.
} 
Starców oraz świetną znajomość głębokich warstw ludzkiej świadomości oraz ukrytych pragnień i motywacji ${ }^{19}$.

Doroteusz zmarł prawdopodobnie po roku 560, a przed rokiem 580. Nauki, które wygłaszał jako opat, zostały spisane przez jego uczniów. Mimo, że klasztor Doroteusza zniknął bez śladu z powierzchni ziemi najprawdopodobniej po inwazji arabskiej, to jednak spisane konferencje, listy i sentencje ocalały i przetrwały przez kolejne stulecia.

Dzieła, które po nim pozostały, stały się szybko klasycznymi pozycjami w literaturze monastycznej, zaś pod względem sławy Doroteusz przewyższył swoich mistrzów. W nauce duchowej Doroteusz dokonał syntezy apoftegmatów, teologii Ojców Kapadockich, Jana Chryzostoma, Marka Eremity i Izajasza z Gazy, a przez Teodora Studytę wywarł wielki wpływ na monastycyzm grecki, rosyjski i arabski ${ }^{20}$.

3. Czynić dobro. Mówiąc o problemach życia duchowego Doroteusz bardzo często posługuje się terminologią medyczną i porównuje zdrowie duszy do zdrowia ciała. W jednej z konferencji podkreśla, że okres rekonwalescencji nawet po ustaniu negatywnych objawów jest bardzo długi, stąd nie należy się dziwić, że zdrowie duszy, gdy ktoś popadł w chorobę grzechu, wymaga także cierpliwości i odpowiedniego czasu oraz wielkiego trudu. Bardzo ważne jest więc, by nie tracić zdrowia duszy ${ }^{21}$. Grzech, a zwłaszcza nałóg czy wada skazują człowieka na mękę ${ }^{22}$. Ostatecznie w każdej okoliczności życia należy pamiętać, że Chrystus jest lekarzem duszy, zna wszystko i „dla każdej namiętności przygotował właściwe lekarstwo"23.

Droga doskonalenia duchowego według Doroteusza składa się z pewnych etapów i charakteryzuje się koniecznością podjęcia duchowej walki²4. Pierwszy etap to wyrwanie starych nałogów i namiętności. Dokonuje się to na drodze pokuty i łez ${ }^{25}$. Dalszym etapem jest pozytywna asceza, w której Doroteusz zaleca pełnienie dobrych czynów. Mnich powinien:

„walczyć, trudzić się, cierpieć [...] atakowany, sam atakując i potykając się z wrogiem, czyni dobro, ale wśród wielkiego ucisku, z wielkim cierpieniem"26.

Ponieważ dusza nie może trwać w bezruchu, ale zawsze do czegoś dąży, to człowiek pragnący zbawienia nie tylko powinien powstrzymać się od zła, ale

\footnotetext{
${ }^{19}$ Por. Borkowska, Wstęp, PSP 27, 7.

${ }^{20}$ Por. J. Gribomont, Doroteo di Gaza, DPAC I 1038.

${ }^{21}$ Por. Dorotheus Gazaeus, Doctrinae universae 11, 113, PG 88, 1734, tłum. M. Borkowska: Różne nauki świętego ojca naszego Doroteusza, ŹM 51, 183.

${ }^{22}$ Por. tamże 11, 122, PG 88, 1746, ŹM 51, 192.

${ }^{23}$ Por. tamże 11, 113, PG 88, 1734, ŹM 51, 183.

${ }^{24}$ Por. L. Wianowski, Walka z namiętnościami i wyrzeczenie się własnej woli jako elementy walki duchowej wedlug św. Doroteusza z Gazy, „Studia Diecezji Radomskiej” 8 (2007) 79-88.

${ }^{25}$ Por. Dorotheus Gazaeus, Doctrinae universae 12, 132, PG 88, 1756, ŹM 51, 202.

${ }^{26}$ Tamże 4, 51, PG 88, 1665, ŹM 51, 118.
} 
czynić dobro ${ }^{27}$. Dobroć, która łączy się zawsze ze stałością i miłością jest wspólną nauką wszystkich ludzi pustyni, także Doroteusza ${ }^{28}$. Praktykowanie dobrych uczynków z gorliwością jest dla opata z Gazy podstawowym narzędziem do walki z namiętnościami. Miejsce starych nałogów powinny zajać nowe cnoty, wśród których najważniejsza jest miłość. Jednym z podstawowych środków, które służyły nabyciu cnót, w tym miłości bliźniego, była opieka nad chorymi. Traktował ją jako najkrótszą drogę wiodącą do oczyszczenia i do doskonałości. W jednej z nauk Doroteusz mówi:

„Kto mądrze usługuje choremu, ten doznaje ulgi w swej walce $\mathrm{z}$ namiętnościami. Znałem brata, który borykał się z nieczystymi żądzami, a został z nich wyzwolony, dlatego, że usługiwał mądrze choremu na dyzenterię"29.

Także Ewagriusz opowiada o pewnym Starcu, że wspomógł skutecznie pewnego brata męczonego po nocach przez takież widzenia. Nakazał mu mianowicie pościć i usługiwać chorym. A gdy go zapytano o przyczynę odpowiedział: Nic tak nie gasi namiętności jak miłosierdzie ${ }^{30}$. Wydaje się, że Doroteusz jest tu kontynuatorem wielkiej tradycji Ojców Pustyni, w której zarówno przyjęcie choroby z cierpliwością, jak i służba potrzebującym oraz kontemplacja mają taką samą wartośćci

Z nauk Doroteusz można wyciąnnąć wniosek, że opieka nad chorymi i starszymi odgrywa ważną rolę w formowaniu mnichów. On sam prowadząc infirmerię i usługując chorym, mógł się przekonać o pożytecznym znaczeniu takiej posługi. Usługiwanie chorym wyrabiało pokorę i współczucie, a także było znakiem miłości i życzliwości wobec bliźniego. Najlepszym przykładem takiego postępowania był wychowanek Doroteusza, Dozyteusz, którego kilkuletnia praca $\mathrm{w}$ infirmerii zaprowadziła do świętości ${ }^{32}$. Przebywanie wśród chorych i doświadczonych starców uczyło początkujących mnichów właściwego i mądrego patrzenia na życie. Szczególnie cenna jest lekcja pokory, gdyż to ona właśnie - według Doroteusza - stanowi istotną cechę życia duchowego oraz strzeże od pokus i namiętności, jak „ogrodzenie wokół domu”33, i ostatecznie pozwala zwyciężać zło ${ }^{34}$. Doroteusz zna dobrze tradycję pustyni i powołuje się na konkretne apoftegmaty, aby podkreślać wagę pokory. Za Antonim podaje, że jedynie pokora jest w stanie wyrwać się ze wszystkich

${ }^{27}$ Por. tamże 12, 133, PG 88, 1759, ŹM 51, 203.

${ }^{28}$ Por. I. Gobry, Storia del monachesimo, I, Roma 1991, 53.

${ }^{29}$ Dorotheus Gazaeus, Doctrinae universae 14, 153, PG 88, 1774, ŹM 51, 222. Por. L. Wianowski, Doskonałość mnicha w pismach Doroteusza z Gazy, Kraków 2016, 60-61.

${ }^{30}$ Por. Evagrius Ponticus, Practicus 15, ed. A. i C. Guillaumont, SCh 171, Paris 1971, 536-538, tłum. E. Kędziorek: Ewagriusz z Pontu, O praktyce ascetycznej, w: Ewagriusz z Pontu, Pisma ascetyczne, t. 1, ŹM 18, Kraków 1998, 210.

${ }^{31}$ Por. Apophtegmata Patrum, Collectio alphabetica 603 (Poemen 29), PG 65, 330, ŹM 4, 395.

${ }^{32}$ Por. Dorotheus Gazaeus, Doctrinae universae 1, 21, PG 88, 1611, ŹM 51, 73.

${ }^{33}$ Tamże 14, 151, PG 88, 1769, ŹM 51, 86.

${ }^{34}$ Por. tamże 2, 26-39, PG 88, 1614-1652, ŹM 51, 74. 
zasadzek szatańskich ${ }^{35}$. Pokora zmienia spojrzenie, nie pozwala skupiać się na sobie, uznając siebie za centrum świata, ale otwiera na współczucie i służbę, oddaje siebie do dyspozycji innym. Opieka nad chorymi jest więc doskonałą drogą uzyskania takiej cnoty. Za wielką tradycją ascetyczną, na którą składa się przede wszystkim duchowość Ojców Pustyni i myśl Ojców Kapadockich, Doroteusz podkreśla, że wszelki trud cielesny i cierpienie ciała prowadzi do pokory $^{36}$. Człowiek doświadczany chorobą otrzymuje więc od Boga możliwość zdobywania tej cnoty i dla tych, którzy się nim opiekują, może być inspiracją, przykładem i drogą do oczyszczenia. Cnota pokory jest cnotą monastyczną par excellence, ponieważ mnich to ten, który naśladuje Chrystusa uniżonego i cierpiącego, pozbawionego niebiańskiej chwały i zjednoczonego z ostatnim z ludzi ${ }^{37}$. Według Doroteusza ta cnota może i powinna być praktykowana we wszystkich okolicznościach życia w chorobie i w służbie chorym, a ponieważ czyni człowieka małym w jego własnych oczach, jest najmocniejsza ze wszystkich cnót ${ }^{38}$.

Ponadto opieka nad chorymi pozwala również naśladować miłosierdzie, które jest cechą charakterystyczną Boga ${ }^{39}$. Doroteusz lubi powtarzać ewangeliczny nakaz: „bądźcie miłosierni, jak Ojciec wasz jest miłosierny” (Łk 6, 36). $\mathrm{Z}$ wielką żarliwością należy więc zabiegać o cnotę miłosierdzia przejawiająca się w czynnej miłości bliźniego.

\section{Wartość choroby. W jednym z listów Doroteusz pisze:}

„Wierz, że naszymi sprawami, aż do najdrobniejszych, kieruje Opatrzność Boża; a tak zniesiesz wszelkie zdarzenia spokojnie" ${ }^{\prime 4}$.

Myśl ta bardzo często powraca w nauczaniu św. Doroteusza. Jest on przekonany, że „wszystko to, co się dzieje, dzieje się albo z dopuszczenia Boga, albo z Jego upodobania" ${ }^{41}$. To Bóg dopuszcza, że ktoś cierpi albo choruje. Bóg dopuszcza głód, zarazę, chorobę, suszę, wojny czy inne klęski często z powodu naszych grzechów i dla nawrócenia ${ }^{42}$. Choroba według Doroteusza powstaje wtedy, gdy człowiek, ,prowadzi nieuporządkowane życie i nie dba o zdrowie i powstaje w nim jakiś niedobór albo nadmiar"43. Święci Barsanufiusz i Jan nauczyli Doroteusza patrzeć na wszystko w świetle Bożej pedagogii, która może

${ }^{35}$ Por. Apophtegmata Patrum, Collectio alphabetica 7 (Antonius 7), PG 65, 78, ŹM 4, 138; Dorotheus Gazaeus, Doctrinae universae 2, 30, PG 88, 1636, ŹM 51, 99.

${ }^{36}$ Por. Dorotheus Gazaeus, Doctrinae universae 2, 39, PG 88, 1643, ŹM 51, 107.

${ }^{37}$ Por. Gobry, Storia del monachesimo, I, s. 53.

${ }^{38}$ Por. tamże, s. 55.

${ }^{39}$ Por. Dorotheus Gazaeus, Doctrinae universae 14, 156, PG 88, 1779, ŹM 51, 227.

${ }^{40}$ Tenże, Epistula 2, 187, PG 88, 1837, tłum. M. Borkowska: Różne listy ojca Doroteusza, ŹM 51,259 .

${ }^{41}$ Tenże, Doctrinae universae 14, 155, PG 88, 1776, ŹM 51, 225.

42 Por. tamże.

${ }^{43}$ Tamże 10, 106, PG 88, 1729, ŹM 51, 176. 
się także manifestować w chorobie. Doświadczając człowieka przez chorobę, Bóg może chcieć go oczyścić z grzechów, zmienić i uświęcić. Takie spojrzenie na chorobę ciała, jako na remedium na choroby duszy oraz okazję do duchowego wzrostu, znajdziemy u Jan Chryzostoma, Jan Kasjana, Grzegorza z Nazjanzu, Maksyma Wyznawcy, Izaaka Syryjczyka, Jana Klimaka i wielu innych Ojców ${ }^{44}$.

Niestety Opat z Gazy w swoich konferencjach nie podejmuje zagadnienia niewinnego cierpienia. Znajdziemy u niego natomiast bardzo często prawdę o tym, że życie człowieka jest próbą i zmaganiem ${ }^{45}$. Bóg jednak zawsze pragnie, by człowiek współpracował z Jego wolą, a dopuszczając cierpienie na kogoś, nie chce by ludzie mu dodawali cierpienia, ale okazywali litość i miłość. W ten sposób jego choroba staje się także dla innych okazją do czynienia dobra. Dlatego Doroteusz przestrzega chorującego przed fałszywą cnotą udawaną w chorobie. W jednym ze swoich listów do brata narzekającego w chorobie nad swoim losem pisze:

„co zaś do tego, że mówisz, iż jesteś ciężarem dla braci, to takie słowa pochodzą z chęci udawania cnoty. Bo nikt dostarczając bliźniemu, który pragnie się zbawić, okazji do wypełniania przykazania Bożego nie mówi: Jestem mu ciężarem”46.

Najważniejsze jest posłuszeństwo Bogu i oddanie się Jemu do dyspozycji. Nawet w chorobie człowiek może być narzędziem Boga służącym do uświęcania innych. Jako wzór zawierzenia Bogu we wszystkim, także w chorobie, Doroteusz przytacza przykład pewnego świętego starca. Ten, gdy był chory, otrzymał zamiast placka z miodem, placek ze szkodliwym dla zdrowia lnianym olejem. Gdy brat, który się nim opiekował, spostrzegł swój błąd, bardzo się zmartwił i zaczął ubolewać nad tym. Starzec jednak z pokorą i w milczeniu zjadł placek i powiedział bratu, że gdyby Bóg chciał, aby on jadł miód, to na pewno dałby mu placek z miodem ${ }^{47}$.

Życiowe próby są zawsze sprawdzianem cnoty. Zachowanie w chorobie czy w starości uważano za sprawdzian osiągniętej doskonałości chrześcijańskiej $^{48}$. Doroteusz, podkreśla, że ten, kto we wszystkim umie zawierzyć Bogu, nie boi się choroby i płynących z niej cierpień. Zwracając się w liście do jednego ze swych braci daje mu taką wskazówkę:

„Wszystko co na ciebie przychodzi przyjmij jako dobre, aby plany Opatrzności Boga spełniły się wobec ciebie, zgodnie z Jego upodobaniem. Bądź wiec odważny, trwaj mocno w Panu i wierności Jego zamiarom wobec ciebie"49.

\footnotetext{
${ }^{44}$ Por. Larchet, Le chrétien devant la maladie, s. 66-71.

${ }^{45}$ Por. Dorotheus Gazaeus, Epistula 12, 197, PG 88, 1841, ŹM 51, 268.

${ }^{46}$ Tamże 16, 201, PG 88, 1848, ŹM 51, 270.

${ }^{47}$ Por. tenże, Doctrinae universae 7, 87, PG 88, 1699, ŹM 51, 156.

${ }^{48}$ Por. E. Stanula, Wstęp, w: Św. Doroteusz z Gazy, Nauki ascetyczne, PSP 27, 21

${ }^{49}$ Dorotheus Gazaeus, Epistula 10, 195, PG 88, 1839, ŹM 51, 266.
} 
Nie każdy człowiek potrafi w chorobie, czy w podeszłym wieku, zachować się z godnością i przyjąć tę sytuację jako dopust Boży. Doroteusz jest świadomy, że

„są ludzie, którym tak ciążą przychodzące na nich cierpienia, że odrzekają się nawet życia i woleliby umrzeć, żeby przez to doznać ulgi" ${ }^{50}$.

Miłosierną służbą wobec takich ludzi byłoby wówczas dobre słowo pocieszenia. Innym dobrym czynem jest jałmużna, pamięć o ubogich i potrzebujących. Wśród Ojców Pustyni i mnichów pierwszych wieków znajdowała ona szczególne miejsce jako środek pozwalający uwolnić się od przywiązań do rzeczy materialnych, jak również jako wyraz miłości bliźniego. Doroteusz także służbę chorym nazywa jałmużną. Podkreśla on, że nikt nie może się z tego obowiązku dyspensować twierdzeniem, że nic nie ma, ponieważ zawsze może dać choremu jałmużnę posługi albo okazać mu miłosierdzie słowem, przebaczeniem, znoszeniem wybuchów jego gniewu ${ }^{51}$.

Opat z Gazy porównuje życie do wędrówki po drabinie, a konkretne czyny do szczebli w tej drabinie. Istotne jest, by nie schodzić „w dół do piekła” i o ile to możliwe wstępować do góry" "52. Oto program świętego Doroteusza z Gazy:

„zadbaj przynajmniej o to, żebyś w dół nie schodził. Nie czyń złego bliźniemu, nie rań go, nie obmawiaj, nie lżyj, nie pogardzaj, a później powoli zacznij czynić coś dobrego. Wesprzyj dobrym słowem swego brata, mając dla niego współczucie, a jeśliby czegoś potrzebował, zrób to dla niego; a tak posuwając się po jednym szczeblu, z pomocą Bożą osiągniesz szczyt drabiny. Bo przez to, że powoli zaczynasz wspomagać swego brata, dochodzisz do pragnienia jego dobra jak własnego i jego korzyści jak własnej”53.

5. Usługiwać nie jak niewolnik czy najemnik. Powołując się na św. Bazylego Wielkiego ${ }^{54}$, Doroteusz wyróżnia trzy postawy u tych, którzy służa Bogu lub ludziom ${ }^{55}$. Kiedy człowiek działa z powodu bojaźni i kary jest niewolnikiem, kiedy działa dla zapłaty jest najemnikiem, ale najwłaściwsza jest postawa syna, który służy dla samego dobra:

„Syn bowiem pełni wolę ojca nie ze strachu, ani dla nagrody, ale ponieważ chce go uczcić, chce go uczcić i zadowolić. I my więc tak powinniśmy pełnić miłosierdzie jak własnym członkom, tak usługując bliźniemu, jakby to on

${ }^{50}$ Tenże, Doctrinae universae 12, 125, PG 88, 1755, ŹM 51, 196.

${ }^{51}$ Por. tamże 14, 158, PG 88, 1784, ŹM 51, 229.

${ }^{52}$ Por. tamże 14, 154, PG 88, 1780, ŹM 51, 223.

${ }^{53}$ Tamże.

${ }^{54}$ Por. Basilius Magnus, Regulae fusius tractatae, Proemium 3, PG 31, 895, thum. J. Naumowicz: Bazyli Wielki, Reguly dłuższe, ŹM 6, Kraków 1995, 39.

${ }^{55}$ Por. Dorotheus Gazaeus, Doctrinae universae 4, 48, PG 88, 1663, ŹM 51, 114; 14, 157, PG 88, 1781, ŹM 51, 228. 
nam usługiwał, tak dając, jakbyśmy to my otrzymywali. To jest miłosierdzie czynione mądrze, przez to okazujemy się synami”"56.

Doroteusz przestrzega, aby, usługując chorym, nie czynić tego dla próżnej chwały czy późniejszej nagrody. Sprawdzianem bezinteresownej służby są trudności, jakie może napotkać posługujący. Są to np. niezrozumienie czy brak wytrwałości. Nauka Opata z Gazy ma swoje źródła biblijne. Według niego zawsze należy kierować się słowami ewangelii: „Taką miarą jaką wy mierzycie, wam odmierzą" (Mt 7, 2) s. $^{57}$ Dobro wyświadczone wraca do człowieka w cudownych zrządzeniach Bożej Opatrzności. W jednym z listów Doroteusz artykułuje zachętę:

„usługuj chorym, przede wszystkim, po to, aby się nauczyć współczucia, jak często powtarzam, a po drugie, żeby i wtedy, gdy ty będziesz chory, Bóg kogoś pobudził do posługi"’58.

Dla Doroteusza ważne jest mądre służenie choremu. Czyni to ten, kto troszczy się o chorych

„dla uczenia się, i współczucia i tkliwego miłosierdzia. Kto ma taki cel, ten cokolwiek by się zdarzyło, choćby i sam chory okazał się niewdzięczny, znosi to spokojnie, mając przed oczyma swój cel; i wie, że to raczej chory jemu wyświadcza łaskę, niż on choremu" 59 .

Kto chce służyć chorym mądrze, powinien mieć przed oczyma wyższy cel i głębsze zrozumienie Bożej Opatrzności. Chory jest dany wspólnocie i poszczególnym osobom jako łaska, jako okazja do oczyszczania i uświęcenia oraz droga do zdobycia mądrości i cnoty pokory. Służba chorym staje się więc jakimś szczeblem w drabinie do świętości.

Doroteusz jest świadkiem wielkiej tradycji Ojców Pustyni, zna apoftegmaty i pisma Ewagriusza z Pontu. Powołuje się często na myśl teologiczną i ascetyczną Ojców Kapadockich i w pewnym sensie dziedziczy po świętym Bazylim Wielkim także wrażliwość na osoby chore i potrzebujące. Spotkał na swojej drodze rozwoju mądrych ojców duchowych, którzy potrafili przeprowadzić go przez trudności i wykorzystali jego wrażliwość, zdolności, a także wiedzę medyczną. Opat z Gazy podkreśla, że na drodze duchowej doskonałości konieczne jest oczyszczenie z grzechów i namiętności, ale kolejnym ważnym etapem jest asceza pozytywna, która polega na czynieniu dobra. Wśród dzieł miłosierdzia szczególnie akcentuje opiekę nad chorymi. Służba chorym

\footnotetext{
${ }^{56}$ Tamże 14, 157, PG 88, 1781, ŹM 51, 228.

${ }^{57}$ Por. tamże 14, 153, PG 88, 1760, ŹM 51, 222.

${ }^{58}$ Tenże, Epistula 4, 189, PG 88, 1839, ŹM 51, 261.

${ }^{59}$ Tenże, Doctrinae universae 14, 153, PG 88, 1776, ŹM 51, 222.
} 
jest służbą samemu Chrystusowi i powinna być podejmowana nie z nakazu, ani nie dla nagrody, ale dla samego dobra. Doroteusz sam doświadczył zbawiennych owoców posługi chorym w infirmerii i jest przekonany, że stanowi ona doskonały środek oczyszczenia z namiętności i jest dobrą lekcją pokory. W relacjach z chorymi następuje niezwykła wymiana dóbr. Chory otrzymuje troskę i opiekę, ale sam staje się dla opiekuna łaską, dzięki której ten uczy się współczucia, czyni dobro i doznaje oczyszczenia. Ten, kto troszczy się o chorego, uwalnia się od skoncentrowania na samym sobie, naśladuje miłosiernego Boga, postępuje na drodze doskonałości i zdobywa życiową mądrość oraz cnotę pokory. $\mathrm{W}$ takim ujęciu choroba i sam chory nabierają znaczenia historiozbawczego i są darem od Boga, który w swojej Opatrzności wszystko potrafi skierować ku dobru człowieka.

\section{CARE FOR THE SICK AS THE WAY TO HOLINESS ACCORDING ST. DOROTHEUS OF GAZA}

\section{(Summary)}

The article presents a part of spirituality of Saint Dorotheus of Gaza, the Palestinian monk and abbot from VI century. He wrote instructions and letters for monks in which one of the topics is also care for the sick. Dorotheus himself before became an Abba was educated in medicine and in monastery was responsible for infirmary. He underlines that after first step on the road of improvement which is purification man must fill his heart with good deeds. Care for the sick is one of them. Dorotheus is looking on disease in the light of Divine Providence. In this way the disease is a trial, but also body sickness could be medicine for the soul. If someone is looking after the sick he has an opportunity to learn humility and wisdom of life. Dorotheus invites monks to do this disinterestedly. By that means sickness becomes a way to holiness.

Key words: Dorotheus of Gaza, Desert Fathers, history of the health care, Palestinian monasticism.

Słowa kluczowe: Doroteusz z Gazy, Ojcowie Pustyni, historia szpitalnictwa, monastycyzm palestyński.

\section{BIBLIOGRAFIA}

\section{Źródła}

Apophtegmata Patrum, Collectio systematica (Verba Seniorum), PL 73, 855-1062, thum. M. Kozera: Apoftegmaty Ojców Pustyni, t. 2: Kolekcja systematyczna, ŹM 9, Kraków 1995.

Apophtegmata Patrum, Collectio alphabetica, PG 65, 71-440, thum. M. Borkowska: Apoftegmaty Ojców Pustyni, t. 1: Gerontikon. Księga starców, ŹM 4, Kraków 2004. 
Basilius Magnus, Regulae fusius tractatae, PG 31, 889-1052, tłum. J. Naumowicz: Bazyli Wielki, Reguty dtuższe, ŹM 6, Kraków 1995.

Benedictus, Regula, ed. tłum. A. Świderkówna: Święty Benedykt z Nursji, Reguła, Kraków 1994, 25-263.

Dorotheus Gazaeus, Doctrinae universae, PG 88, 1617-1836, thum. M. Borkowska: Różne nauki świętego ojca naszego Doroteusza, w: Doroteusz z Gazy, Pisma ascetyczne, ŹM 51, Kraków 2010, 73-250.

Dorotheus Gazaeus, Epistulae, PG 88, 1793-1841, tłum. M. Borkowska: Różne listy ojca Doroteusza, w: Doroteusz z Gazy, Pisma ascetyczne, ŹM 51, Kraków 2010, 251-273.

Dorotheus Gazaeus, Vita s. Dosithei, PG 88, 122-144, tłum. M. Borkowska: Doroteusz z Gazy, Żywot św. Dozyteusza, w: Doroteusz z Gazy, Pisma ascetyczne, ŹM 51, Kraków 2010, 58-71.

Evagrius Ponticus, Practicus, ed. A. i C. Guillaumont, SCh 171, Paris 1971, thum. E. Kędziorek: Ewagriusz z Pontu, O praktyce ascetycznej, w: Ewagriusz z Pontu, Pisma ascetyczne, t. 1, ŹM 18, Kraków 1998, 201-230.

\section{Opracowania}

Borkowska M., Twarze Ojców Pustyni, Kraków 2001.

Borkowska M., Wstęp, w: Starcy spod Gazy. Wybór pism Barsanufiusza, Jana, św. Doroteusza z Gazy, BOK 11, Kraków 1999, 5-21.

Borkowska M., Wstęp, w: Św. Doroteusz z Gazy, Nauki ascetyczne, PSP 27, Warszawa 1980, 5-11.

Cesera A., L'Ospedale e l'assistenza ai malati nel corso dei secoli, Brezzo di Bedero 1994.

Chryssavgis J., W sercu pustyni. Duchowość Ojców i Matek pustyni, tłum. M. Chojnacki, Kraków 2007.

CRISLIP A.T., From Monastery to Hospital. Christian Monasticism and the Transformation of Health Care in Late Antiquity, Michigan 2005.

Ferngren G.B., Medicine and Health Care in Early Christianity, Baltimore 2009.

Gobry I., Storia del monachesimo, I, Roma 1991.

Gribomont J., Doroteo di Gaza, DPAC I 1038.

Hevelone-Harper J.L., Uczniowie pustyni. Mnisi świeccy i prymat ducha w Gazie VI wieku, tłum. E. Dąbrowska, ŹM 52, Kraków 2010.

LARChET J.-C., Le chrétien devant la maladie, la souffrance et la mort, Paris 2002.

Longosz S., Ksenodochium - hospicjum wczesnochrześcijańskie, VoxP 16 (1996) t. 30-31, 273-336.

Nieścior L., Wstęp, w: Doroteusz z Gazy, Pisma ascetyczne, ŹM 51, Kraków 2010, 13-38.

PawŁowska-BlachaczeK B., „, Corpora sanctorum in pace sepulta sunt, et nomina eorum vivent in aeternum”. Peregrinatio christiana do Rzymu w czasach Grzegorza Wielkiego, VoxP 30 (2010) t. 55, 77-93.

ŠPiduIK T., Duchowość chrześcijańskiego Wschodu. Poradnik systematyczny, tłum. L. Rodziewicz, Kraków 2005.

Stanula E., Wstęp, w: Św. Doroteusz z Gazy, Nauki ascetyczne, PSP 27, Warszawa 1980, 12-28.

Wianowski L., Doskonałość mnicha w pismach Doroteusza z Gazy, Kraków 2016.

WiANOWSki L., Walka z namiętnościami $i$ wyrzeczenie się własnej woli jako elementy walki duchowej wedtug św. Doroteusza z Gazy, „Studia Diecezji Radomskiej” 8 (2007) 79-88. 